\title{
The domestic risk of Chinese partnerships: cross-conditionality and coalition building
}

\author{
O risco doméstico das parcerias com a China: a condicionalidade cruzada e a construção de coalizões
}

DOI: https://doi.org/10.22456/2178-8839.106429

Alejandro Angel

Universidade Federal de Santa Catarina, Florianópolis, Brasil

alejandro.angel@posgrad.ufsc.br

\begin{abstract}
Chinese credits became a viable, and preferred, alternative during the pink tide in part because it lacked traditional conditionality clauses. However, these financial operations, as well as others, often imply the existence of cross-conditionality. In opposition to traditional variants of conditionality, cross-conditionality implies that operations in the realms of trade, finance, or aid for development can be jeopardized as a response to decisions taken by national authorities that change previously agreed conditions in parallel projects. The main objective of this study is to explore the possible consequences of cross-conditionality, particularly the political consequences, in the Brazilian government's coalition building. The hypothesis is that cross-conditionality represents a similar risk than the one that traditional conditionality represented in terms of national autonomy insofar as national governments would still have their hands tied, although for different reasons. We find that cross-conditionality affects the coalition-building efforts of national governments since it can be used to affect key government partners. In Brazil, agribusiness, a key partner of Bolsonaro's government, is the sector that could be potentially affected if the Chinese government decides to implement cross-conditionality as a retaliatory measure to hostile policies or declarations of the Brazilian government vis-à-vis Chinese interests.
\end{abstract}

Keywords: Cross-conditionality; Second-image reversed; Coalitions; China; Brazil;

\section{Resumo}

Empréstimos chineses se tornaram alternativas viáveis de financiamento durante a onda rosa devido à ausência de cláusulas de condicionalidade tradicionais. No entanto, essas operações financeiras, além de outras de diversos tipos, implicam com frequência a condicionalidade cruzada. Contrário à condicionalidade tradicional, a condicionalidade cruzada implica que operações nas áreas de comércio, financeira ou de ajuda ao desenvolvimento sejam prejudicadas em resposta a decisões de autoridades nacionais que mudem condições de projetos paralelos. O objetivo do presente trabalho é explorar as possíveis consequências políticas da condicionalidade cruzada na coalizão de sustentação do governo brasileiro. A hipótese é que a condicionalidade cruzada representa um risco similar àquele da condicionalidade tradicional em termos de autonomia nacional, mas por motivos diferentes. Se conclui que a condicionalidade cruzada afeta os esforços governamentais de construção de uma coalizão de governo devido aos impactos potenciais que ela possa ter sobre parceiros importantes do governo. No Brasil, o setor agroexportador, parceiro chave da coalizão do governo Bolsonaro, seria aquele que poderia ser potencialmente afetado se o governo chinês decide implementar a condicionalidade cruzada como medida de retaliação a políticas ou declarações hostis do governo brasileiro a respeito de interesses chineses.

Palavras-chave: Condicionalidade cruzada; Segunda imagem invertida; Coalizões; China; Brasil 


\section{Introduction}

China has become an important economic partner for many Latin American countries. The spheres in which such partnership is evident range from the changes in trade patterns (OURIQUES; ARIENTI, 2017), stronger financial ties through loan operations within the framework of aid for development (CRIVELLI; LO-BRUTTO, 2018), or in the increasingly important commercial ties between them (MALACALZA, 2019). Chinese loans have increased, in part, because many of them do not have the traditional strings attached that could create political costs for politicians who decide to take them - i.e., institutional reforms in exchange for loans. After many years of structural adjustment loans with heavy conditionality clauses, Chinese lending became a viable, and preferred, alternative to break the cycle of what was largely considered across the region as the imposition of the Washington-based international financial organizations (VADELL, 2018, p.18-19). ${ }^{1}$ These changes took place when the pink tide was in full force in Latin America (CAMERON; HERSHBERG, 2010; LEVITSKY; ROBERTS, 2011).

This ideological association led to a renewed enthusiasm of Latin American governments to take a variety of resources as if they presented an intrinsic advantage derived from that ideological connection. While left-leaning governments were keen to emphasize their closeness to China, their successors from the Right fell into the same trap. They assumed that China's presence and actions in the region were a matter of ideology. However, such ideological and political association - emphasized on both sides of the political spectrum in Latin America - was not as important to the Chinese counterpart. ${ }^{2}$ In fact, the pretended ideological association between the Chinese government, on one side, and left-leaning Latin American governments, on the other, has represented in recent times an obstacle rather than an advantage. For instance, anti-China rhetoric has already caused some drawbacks for Latin American countries (RIBEIRO; MILANI, 2019; RITTNER; KRÜGER; ARAÚJO, 2019).

The changes that the new presence in the region implied, ended up eliciting questions about the role that China would come to play in Latin American economies in the twenty-first century (ELLIS, 2014). If there was enthusiasm about the possibilities and meanings of that increased presence, mainly linked to what was perceived as soft power (CHANTAL, 2015; DUARTE, 2012), the last decade has shown that such a partnership would entail costs of its own. Moreover, as the world continues to evolve, the need of many countries in the region to balance foreign policy trade-offs will become ever more evident. Although many of these challenges have been building-up in the last decade (GALLAGHER, 2016), the recent changes in the global landscape will increase the pressure on Latin American governments on having a clear stance on many of those issues.

One of the issues with which governments in the region will have to cope in the future is the escalation of Chinese assertiveness in several arenas. Of particular interest for this contribution is the Chinese use of cross-conditionality as a strategy in the conduction of economic relations with Latin America. In opposition to traditional variants of conditionality, cross-conditionality implies that operations in the realms of trade, finance, or aid for development can be jeopardized as a response to decisions taken by national authorities that change previously agreed conditions in parallel projects (MATTLIN; NOJONEN, 2015, p.712-714). Cross-conditionality constitutes a plausible mechanism to coerce Latin American governments in the context of growing economic relationships between the region and China. Its analysis also sheds light about the risks incurred when signing deals with a strong emerging power. Also, the study of cross-conditionality might show that hopes about how Chinese cooperation would break the cycle of political restrictions derived from economic conditions - e.g., Structural Adjustment Loans - were largely premature.

The main objective of this study is to explore the possible consequences of cross-conditionality, particularly the political consequences, in the Brazilian government's coalition building. We consider that the recent changes that have

\footnotetext{
${ }^{1}$ For an in-depth analysis of these organizations, see WOODS (2006). On the other hand, a more critical take is provided by PEET (2009).

${ }^{2}$ Chinese relations with Latin America were indeed ideological at the height of the Cold War, however, after Deng Xiaoping the relationship has emphasized the economic dimension, with some exceptions (LANTEIGNE, 2020, p.213-214).
} 
taken place in domestic political systems, i.e., the turn to the right, as well as changes in the international arena, i.e., a more assertive presence of China in the region, could trigger episodes in which cross-conditionality might be utilized more frequently. Indeed, if this were the case, this would be a significant challenge to domestic political coalitions and alliances on which national governments rely to advance their agendas. Our hypothesis is that cross-conditionality represents a risk similar to traditional conditionality, mainly in terms of national autonomy insofar as national governments would still have their hands tied, although for different reasons.

This study presents a classical problem of international relations: the impact that international or systemic variables have over domestic ones. In particular, the impact of Chinese cross-conditionality materialized in relation to cooperation agreements, financial operations, or the presence of Chinese companies in the coalition building efforts or economic policy decisions that national governments in Latin America might undertake. We propose to apply a theoretical framework seldom used to analyze these issues in the Latin American region, that is, the literature on the Second Image Reversed (ALT et al., 1996; KEOHANE; MILNER, 1996). ${ }^{3}$ Such theoretical framework concerns mainly with economic phenomena given its emphasis on the marginal effects of changes in the variables of interest. The methods of preference in the overwhelming majority of those works are advanced statistics mainly because of the easiness to calculate those marginal effects. In the present work, we use an asymmetric comparison (KOCKA, 1999) that would allow us to assess the political effects without necessarily focusing on the marginal impact. Even if the debate about Second Image Reversed was prominent in the 1990s, only to lose its appeal afterwards, we consider that its use is appropriate to answer the question of interest in this work.

We study the case of Brazil with asymmetric references to the case of Argentina, which has been affected by crossconditionality, showing the potential risks such strategy entails for Latin American governments. On the other hand, the plausible mitigating factors of the Brazilian case will be analyzed insofar as it showcases in which sectors crossconditionality is more likely to appear as well as the political consequences that such risks will represent. The rest of the article is divided in four sections; the first section will present and contextualize the literature on the Second Image Reversed; the next two sections will discuss the methodology of asymmetric comparison and the case of Brazil respectively. The final section will present some preliminary conclusions.

\section{Second Image Reversed}

The debate about the second image reversed was identified by COHEN (2008) as one of the main topics in American international political economy scholarship. That characterization is confirmed with how influential manuals depict the main disciplinary debates (e.g. FRIEDEN; MARTIN, 2002). The notion of images or levels of analysis goes back to the pioneering work of WALTZ (2001), where he argues that the causes of war can be explained through a recourse to different levels or images: first, individuals and their idiosyncrasies; second, states and their domestic problems may lead them to declare war; and, finally, third, the international system, of which anarchy is the defining principle, can also lead states to declare war. A key point in the argument of Waltz is how such levels or images are independent from one another. However, such idea was increasingly questioned by the changes that took place in the world stage through the 1970s, e.g. oil shocks, the end of the American dollar convertibility, and the combination of inflation and unemployment in the advanced industrial capitalist economies, among others.

In many of these issues, it was evident that events of the systemic arena had their causes in variables that were considered as strictly domestic, that is, within the realm of nation-states. Thus, the notion that domestic policies could have significant impacts on the international arena was ever more evident and, as a consequence, was embraced by some

\footnotetext{
${ }^{3}$ The work of BADIN (2003) constitutes an example of a study conducted in the Latin American context that makes explicit reference to the contribution of KEOHANE and MILNER (1996).
} 
scholars (KATZENSTEIN, 1978). How the different levels related to one another was continuously questioned, this time, however, with an idea that would have enormous impact years later. Contrary to the first questions where domestic variables affected systemic ones, the attention shifted to the impact that systemic variables would have over domestic ones, in what would be called the Second Image Reversed (GOUREVITCH, 1978). Even if in hindsight, such fluidity seems common sense, at the time these ideas represented a challenge to the disciplinary mainstream. In fact, Realism main text was published soon thereafter (WALTZ, 1979), elevating to the status of received wisdom the idea of total independence between domestic and systemic arenas.

However, since economic flows increased with liberalization in several countries, during the 1980s scholarly interests focused on how international economic phenomena affected economic policy decisions (KATZENSTEIN, 1985). Meanwhile, the focus on economic matters created a trend in which the concepts and analytic tools traditionally used in economics became common in international political economy scholarship. An example of this were studies that used variations of the Stolper-Samuelson theorem (STOLPER; SAMUELSON, 1941). In particular, those that study the impact of price increases in the main export of a country, that subsequently improve the relative position of the owners of the main production factor of those exports, changing in turn the balance of power in that country. ${ }^{4}$ Works on the alliance between iron and the rye, making reference to the alliance between metallurgical workers and landowners in the creation of the first incarnations of the German Welfare state in the 1870s (ROGOWSKI, 1989), show this phenomenon. As a consequence of industrialization, and the increasing importance of export markets for heavy industrial products, workers gained an important leverage within domestic politics.

In a world witnessing the end of the Cold War as well as an new wave of democratization (O'DONNELL, 1993), economic liberalization was their corollary. Studies focused on attempts to explain how changes in trade patterns and financial flows could change emerging democracies or transitional economies. An example of those studies that focused on Latin America was that of FRIEDEN (1991). It is an study in what he calls Modern Political Economy, that is, a study of how rational actors maximize their profits, within or outside institutions, given a series of restrictions. The argument is reminiscent of basic economic models in which the main interest is to determine and quantify marginal effects, both economic and political ones. Later on, in the mid-1990s, there were attempts to organize and systematize that body of literature (ALT et al., 1996; KEOHANE; MILNER, 1996).

Given the importance of financial flows for development countries, whether because of foreign debt, their impact on balance of payments, or for currency speculation, the empirical evidence in many of those studies focused on the capital account liberalization. The reason for many developing countries to liberalize their capital accounts was the increasing economic interdependence as well as the pressure that actors that would benefit from such a move created over their respective governments. On the other hand, another mechanism to explain that policy change was the need to implement it as a response to financial crises since openness would signal to foreign and domestic investors that governments were committed to fiscal discipline (HAGGARD; MAXFIELD, 1996). Similar arguments were also mobilized in relation to the reforms that many countries implemented to grant independence to their central banks (MAXFIELD, 1997).

A recurrent criticism levelled against that literature is the intensive use of the hypothetical-deductive logic as well as heavy statistics. ${ }^{5}$ A reason for that methodological preference is the alignment between the kind of questions privileged in many of those studies and the logic of statistical models that measure quantitative marginal effects. Thus, many of those studies try to identify the impact of changes in the international arena over domestic phenomena through marginal changes in the variables studied. Without falling into criticisms about how those are method-driven studies, in opposition

\footnotetext{
${ }^{4}$ The theorem and the conclusions derived from it, however, are not without their critics. For an example, see DAVIS and MISHRA (2007).

${ }^{5}$ A discussion about the consequences of those preferences - mainly present in American International Political Economy scholarship - and the relation with other questions and debates that take place in the discipline elsewhere, was compiled in two issues of New Political Economy in September 2009 (Vol. 14, issue 3) and the Review of International Political Economy in April 2009 (Vol. 16, issue 1). If the discussion in those volumes focuses on the divisions that exist in both sides of the (North) Atlantic, it is a useful reminder about the challenges and shortcomings of Second-Image-Reversed studies.
} 
to real-world questions (SHAPIRO, 2002), an effort that is well beyond the scope of the present contribution, is rather clear that quantitative methods do play an important role in studies within the Second Image Reversed tradition (MALINIAK; TIERNEY, 2009, p.18-22).

Thus, part of what LAKE (2006) calls Open Economy Politics is based on the combination of increasingly complex statistical methods to understand political matters affecting modern economies. In so doing, the interdisciplinary debate between international relations, political science, and economics improved with those efforts. The debate about the Second Image Reversed had an sizable impact on the discipline of International Political Economy, mainly in the US. ${ }^{6}$ Even though other debates had arisen over the years (JOHNSON et al., 2013), making their mark on the discipline, e.g. financial governance, banking regulation, or institutions, concerns about the impact that the international system has over domestic economies continues to drive significant parts of research. Despite all the criticisms leveled against that debate in ontological, epistemological, and methodological terms, we consider that this question is worth asking, even if not following the traditional contours of the scholarship traditionally identified with it.

Although is not the main focus of the article, is worth noting how the second image - that is, traditional foreign policy analysis - has changed in Brazil in the last two decades. Traditionally, the Ministry of Foreign Affairs enjoyed a monopoly on foreign matters. In recent years, however, with a renewed emphasis on South-South cooperation initiatives, a new set of actors have started to participate more actively in the definition of foreign policy. For instance, all ministries, with the obvious exception of the Ministry of Foreign Affairs, have a bureau charged of international affairs, a trend that can also be observed in other levels of government, especially among states' governments. These developments have forced the Ministry to put in place some efforts to preserve a degree of control over the means of foreign policy (FARIA, 2012). However, as political debate around foreign policy increases, a significant group of actors start to participate and attention must be given to issues that might have remained hidden before. This is the case of what is commonly referred to as low politics; examples of those issues are health (DAUVERGNE; FARIAS, 2012; PITTAS; DRI, 2017), human development (PINHO, 2013), education, and agriculture (FARIA, 2012), among others. This participation of new actors in the definition of Brazilian foreign policy represents, in effect, a change with respect to what happened before.

Another key trend in Brazilian foreign policy is its increasing politization. Despite the impression of a rupture in the conduction of Brazilian foreign policy during Lula's government, there were important continuities and adaptations. For instance, the "politization" of the ministry staff signaled the rise to key posts of several career officials who were left aside during Cardoso presidency, who represented a specific tradition within the Ministry. The first tradition, that of Lula's Chancellor, is that of developmentalism, which emphasizes the importance of national development and national autonomy; on the other hand, the second tradition, that of Cardoso's Chancellor, is that of liberalism which emphasizes a liberal order focused on a more aligned position with United States (PECEQUILLO, 2008). There are not enough elements to support the hypothesis of a complete rupture in the conduction of Brazilian foreign policy during Lula's tenure, although some change might have taken place. While Lula tried to capitalize his personal history in order to gather some support from a diversity of political actors in the international arena, Fernando Henrique Cardoso also tried to capitalize his prestige as a recognized academic to improve the country's image in the international community (DUARTE; VIANA, 2008). However, recent indications of politization appeared with the government of Jair Bolsonaro (2019-2022), which started even before he took office (LIBÂNIO, 2018). In fact, politization might increase the risks of cross -conditionality. The next section will briefly discuss the methodology followed in the present study.

${ }^{6}$ An example of that impact is the preeminent role those questions play in popular disciplinary manuals (e.g., FRIEDEN; LAKE; BROZ, 2017) 


\section{Methodology}

As mentioned above, we will implement an asymmetric comparison (KOCKA, 1999). The interest of using this method is to primarily understand the case of interest, through the lens of brief references to analogous cases, highlighting peculiarities of the main case. In the present work, the case of interest is Brazil and we will use the case of Argentina to underscore key aspects of the consequences of cross conditionality. Argentina has a history of trade conflicts with China and also elected a right-leaning president who intended to rebalance the country's foreign policy away from Chinese influence. Even if a traditional binary comparison would be also of interest (GAZIBO, 2002), the Brazilian case is interesting because the reaction against the Chinese weight has been stronger that what was registered in Argentina. Moreover, the Brazilian government also possesses organizations and policy instruments, such as a national development bank, that could potentially mitigate the effects of cross conditionality, particularly when related to infrastructure projects.

Asymmetric comparison differs from traditional case studies (ROHLFING, 2012) because the inferences and conclusions drawn from it make explicit reference to other cases, because they allow to emphasize an important point for the case of interest. On the other hand, asymmetrical comparisons might mitigate some risks of binary comparisons, particularly when the latter would lead to obvious conclusions given the stark contrasts between two possible cases. They seek to highlight key issues of a case of interest without the necessary recourse to a more complex comparative structure, whether by variables or cases (RAGIN; ZARET, 1983). One of the reasons to propose such methodological strategy is to avoid analyses with $a$ priori defined results, due to the nature of the cases. These comparisons are called "ventriloquist comparisons," because the differences in the variables or cases is so evident that the results are quite obvious (HASSENTEUFEL, 2000). In the case of the present contribution, a traditional comparison of the effects of Chinese crossconditionality over coalitional dynamics and the potential mitigating factors that recipient governments could implement, would lead us to the obvious conclusion that having a strong financial position - in the form of the Banco Nacional de Desenvolvimento Econômico e Social (BNDES) - would shield Brazilian initiatives in opposition to Argentinean ones.

For instance, from a methodological point of view, is not easy to define what should be the best comparative framework between the Argentinean and Brazilian cases. As mentioned above, Brazil has some financial leeway since it commands the BNDES, whereas Argentina does not have any similar recourse, leading us to the obvious conclusion that having financial means allow states to conduct their foreign and trade policies more freely. Moreover, in Argentina there has been another government alternation with the return of a Peronist government led by Alberto Fernández (2019-2023). This new change further prevents the elaboration of a traditional comparison between Brazil and Argentina since it was precisely the successive Peronist governments that deepened the partnership between Argentina and China. In sum, all these reasons lead us to prefer an asymmetric comparison focused on the Brazilian case instead of a traditional binary comparative structure.

Nevertheless, if a traditional comparison does not offer ideal conditions, occasional references within the frame of an asymmetric comparison can reveal important issues of the case of interest. Thus, following the advice of KOCKA (1999, p.49), we would still use Argentinean experiences to highlight the Brazilian case, our case of interest. With the aim of adding analytical leverage and avoiding the risks that HASSENTEUFEL (2000, p.108) signals, some alternative hypotheses will be explored in order to better support the conclusions of the asymmetric comparison proposed here. Moreover, the present study can also contribute from a methodological perspective to the studies of South-South cooperation, particularly those referred to economic issues. The next section will focus on the empirical section of this study. 
Brazil

The complicated equilibrium that the current Brazilian Administration must orchestrate between its different priorities in foreign policy concerning its position vis-à-vis China is of the utmost importance giving the high costs any miscalculation can create. Such journey started before the inauguration of President Jair Bolsonaro (2019-2022), when he and his advisors on international affairs had troubling attitudes. Those actions - including comments about the commercial relation between the two countries as well as a visit to Taiwan - did not please authorities in Beijing, causing uneasiness and, at the end, rarefied the ambience between both governments (LIBÂNIO, 2018, p.302). Allegedly, the reason for those actions was that the ideological proximity between the previous administration and China was behind the increase in the commercial flows between the two countries. Thus, since Brazil was going through a severe economic crisis, the country did not gain enough with that association and, so the argument went, it wasted the opportunities offered by other partners, i.e., the United States. These attitudes show how the Right in Latin America also assumed that the presence of China in the region was merely ideological, instead of a more multifaceted array of economic interests. ${ }^{7}$

In response to the public manifestation of such attitudes, the Agribusiness Parliamentary Group (Bancada ruralista) made a statement in favour of a pragmatic economic policy in tandem with the main economic authorities commanded by the Minister of Economy, Paulo Guedes (CHATIN, 2019, p.125-126). This group represents the interests of agricultural and livestock producers, as well as actors of its support industries (e.g., machinery), constituting a key member of the government coalition in congress. Although this is hardly the first time that business stakeholders linked to Agribusiness defended their interests in relation to a matter of Brazilian international trade and foreign policy (e.g., IGLÉCIAS, 2007), this is the first time in which that Parliamentary group is closely aligned with the sitting government. Despite it being a member of the government coalition, such group does not hesitate to criticize the government openly in order to defend its interests. This, rather odd, political action indicates the fragility of the government coalition and how the latter responds to developments in the international arena. In many ways, this is not at all surprising given the increasing importance that agribusiness has acquired in Brazilian trade patterns in general (Figure 1) and, particularly, in the commercial relationship with China (SILVA; MENDONÇA, 2017, p.82).

Figure 1-Soybeans in Brazilian Trade with China. 2001-2019

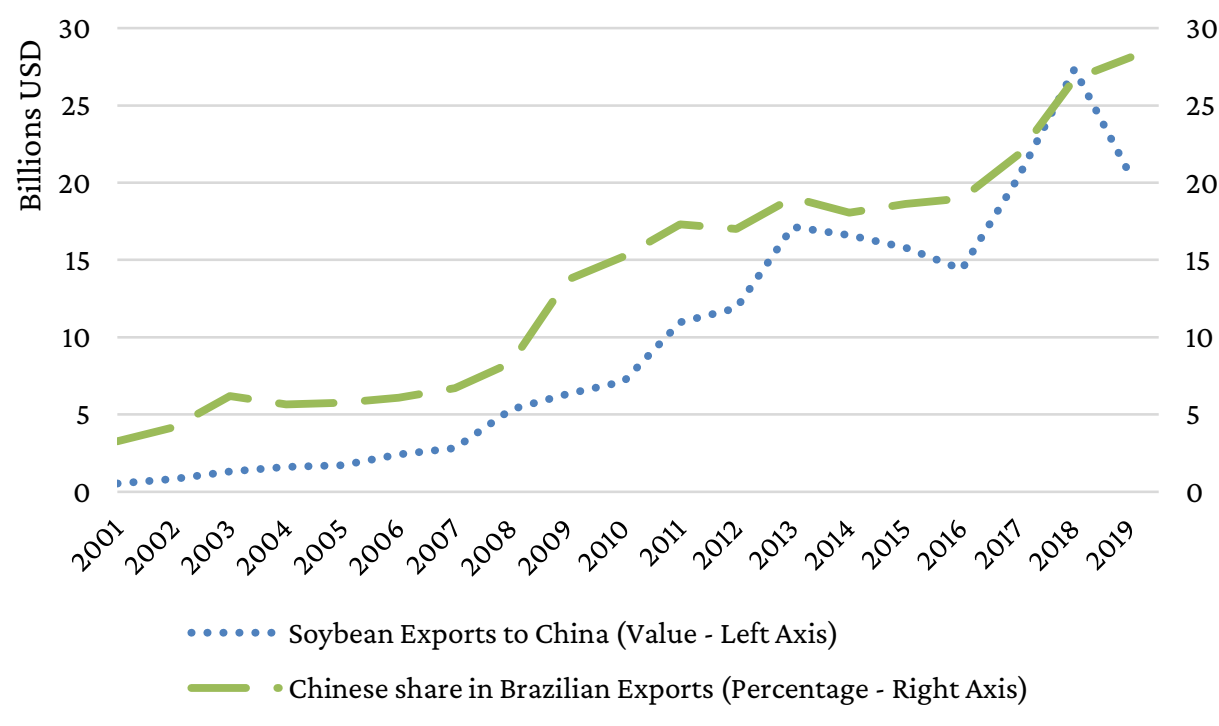

\footnotetext{
${ }^{7}$ Chinese commercial interests took a different dimension with the complex process of accession to the World Trade Organization during the 1990s (KENT, 2013, p.153ff), culminating in 2001 with its full membership
} 
Thus, the weight of the Agribusiness parliamentary group in the current government is the product of three different processes. First, there has been a consolidation in the political representation of agribusiness through the strengthening of the industry representation, that started in the midst of the transition to democracy (BRUNO, 2017). Second, as mentioned above, the weight of agricultural commodities in Brazilian trade patterns has increased steadily during the present century. This fact is in line with the hypothesis of the Stolper-Samuelson theorem (STOLPER; SAMUELSON, 1941), and mirrors what ROGOWSKI (1989) describes for German workers in the late nineteenth century. In both cases the domestic political weight of the owners of the main productive factor of the increasingly important economic activity - i.e., landowners in the Brazilian case - improved accordingly. Finally, the third process explaining the political weight of agribusiness is the political alignment with the government, which gives to agribusiness an important role in the current political juncture in Brazil (DAIA FIRMIANO, 2020).

While international trade is hardly the only topic in which the Agribusiness Parliamentary Group and the government of Jair Bolsonaro share a vision, the latter would be wise to tread carefully when handling such an issue. The integrity of the government's coalition depends in part on the effects that some government's decisions have, or potentially have, on Chinese interests. Were these affected in any way, they can press key members of the government's coalition, hamstringing one of the government's partners (FLORES; JATOBÁ, 2016), as an attempt to obtain concessions. That international trade becomes deeply entrenched in the congressional coalitional dynamics is, somehow, path-breaking in the Brazilian context. ${ }^{8}$ After all, trade affairs are exclusive competence of the Executive Branch (BONELLI; PINHEIRO, 2008), which could lead us to believe that the government possesses significant leeway in the conduction of commercial policy. However, given the imbrication and close political association between agribusiness and the government, the latter must take into account the former's interests.

An arena of potential conflict due to the importance for all involved is that of soybeans. Indeed, soybeans production came to play an increasing important role in the trade relation between Brazil and China in the course of the present century (ROLDÁN et al., 2016, p.48). In addition, Chinese interests now control the trading firms through which soybeans are exported (ROCHA; BIELSCHOWSKY, 2018, p.20-24), increasing the vulnerability of that production to the whims of a single partner. Therefore, is no wonder that, as mentioned above, representatives of agribusiness have called for a more pragmatic approach in the conduction of foreign policy in conjunction with the Ministry of Economy. Indeed, there is a precedent in the recent past when soybean imports were the subject of retaliation from the Chinese government. Such episode took place when soybean commercial operations were suspended in response to the indictment of Chinese officials by an Argentinean judge on human rights offenses (OVIEDO, 2012). Such episode is a clear example of cross conditionality in which the Chinese government tries to press its trade partners to punish them for what it considers sensitive issues.

Brazilian exports of soybeans to China are five times what Argentinean exports are (Figure 2), which potentially indicates that a retaliation is less likely given the sheer volume Brazilian production represents. In fact, the data shows that China might be hedging its disputes with Argentina through its Brazilian imports; the correlation coefficient of the series for the 2010s - that is, after the dispute with Argentina - is close to -1, which implies that each seller is winning when the other is losing. Moreover, is important to keep in mind that the Chinese government does not hesitate to retaliate in a trade dispute, even if it hurts its immediate domestic interests (e.g., ECONOMIST, 2019). Therefore, the potential for a trade spat caused by the Brazilian government's carelessness is considerable and its consequences are in line with the depth of the dispute. Even if soybeans trade between Brazil and China have reached record highs due to a number of factors (SINGH, 2020), is no less true that domestic political stakes are equally high. An indicator of this stakes manifests when

\footnotetext{
${ }^{8}$ This, by no means, implies that trade policy had been conducted without considering coalition building in the domestic realm. Before the liberalization of international trade in the late 1980s and early 1990s, the Customs Policy Commission (Comissão de Politica Aduaneira) attended many corporatist interests (BAUMANN; RIVERO; ZAVATTIERO, 1997, p.559) - many of which supported the government at the time - highlighting the Commission's role in maintaining support for the government. Later on, the liberalization schedule in the early 1990 s also responded selectively to specific interests (KUME; PIANI; SOUZA, 2003) so as not to alienate potential supporters.
} 
actors related to agribusiness, which would otherwise be happy for their proximity to power, express their uneasiness with the way the government has handled communication related to some trade affairs (SAMORA, 2020).

Figure 2 - Exports of Soybeans to China. Argentina and Brazil. 2001-2019 Trade Value (Billions USD)

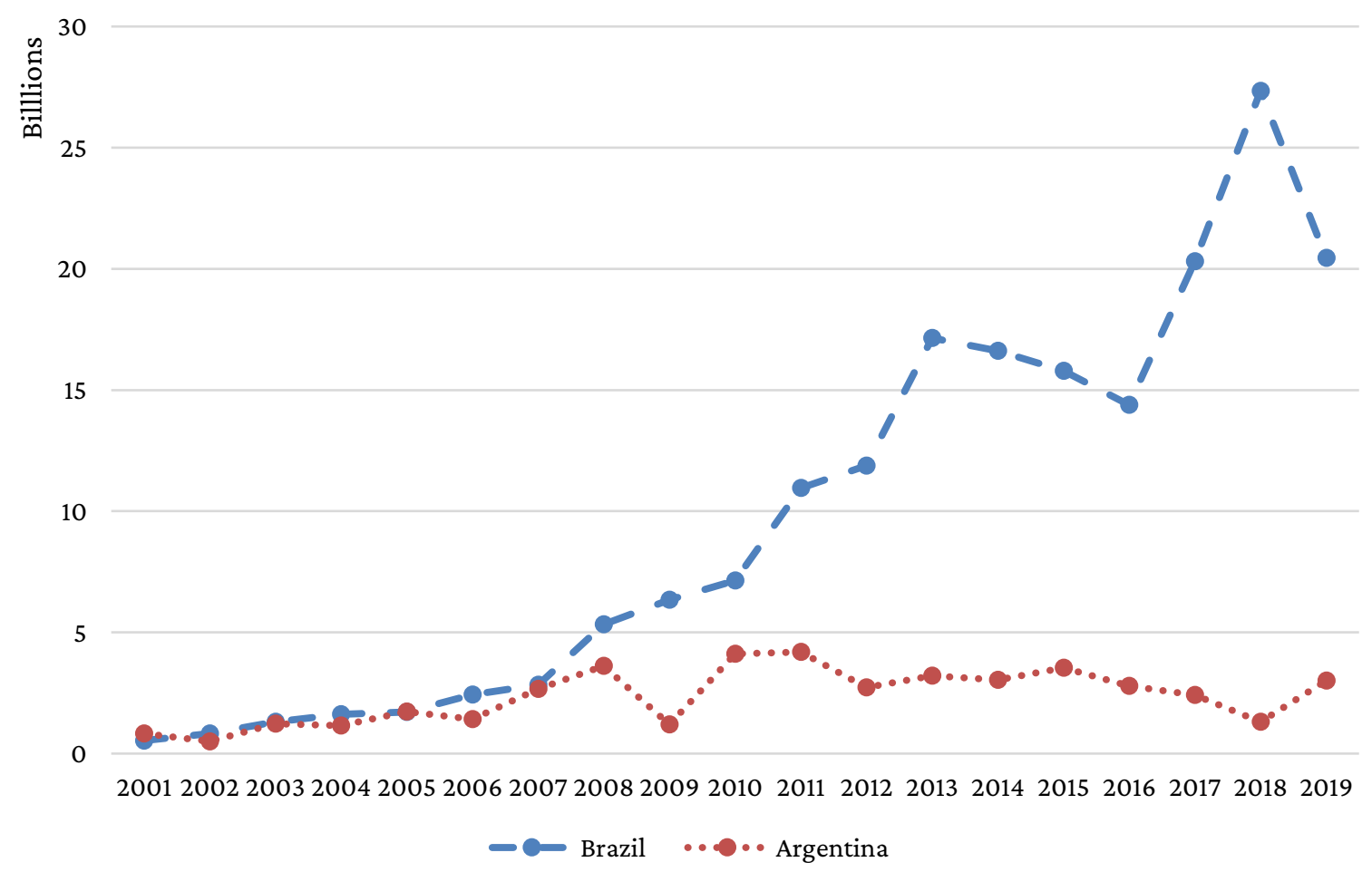

2001-2019: correlation $=0.3901 \mid 2001-2009:$ correlation $=0.5518 \mid 2010-2019:$ correlation $=-0.8380$

Sources: elaborated by the author with data from UN Comtrade (2020).

Commodities are not the only sector at risk of retaliation in a potential trade dispute between Brazil and China. Another sector at risk is that of infrastructure projects, particularly those in the area of energy and utilities which represented the second highest recipient of Chinese direct investment between 2003 and 2016 (AVENDANO; MELGUIZO; MINER, 2017, p.11). However, in such arena the Brazilian position is stronger since it possesses the financial means to weather an eventual spat with a Chinese partner. A case in point is the electrical transmission line coming from the Belo Monte Hydroelectric Dam, which was adjudicated to a consortium between the Chinese group "State Grid" and the Brazilian state-owned Eletrobrás. In spite of the Chinese participation, the project is financed through the BNDES (2018), which limits to a certain extent the possible use of cross-conditionality with respect to that kind of initiatives. ${ }^{9}$

In fact, an infrastructure project in Argentina became the focal point in one episode of cross-conditionality because the government of Mauricio Macri (2015-2019) wanted to backtrack on the construction of a hydroelectric dam. This, however, would cut financing for a railroad with no connection to that project (PATEY, 2017). While in this case, financial resources came entirely from the NDB, giving the Chinese government more leverage, is clear that the involvement of Chinese construction conglomerates is as important as the financial portion of the deals. After all, such participation is also Chinese. Currently, the Brazilian government is potentially in the middle of a similar conundrum: Brazilian authorities have created hurdles that hamper Chinese investments in big infrastructure projects as part of its reorientation of foreign policy. Meanwhile, agribusiness fears a reduction in future Chinese business and tries to use its

${ }^{9}$ These conditions also highlight the risks involved in projects financed through the New Development Bank - NDB, of which China is the main partner (ABDENUR; FOLLY, 2017; RIBEIRO; MARINGONI, 2019), potentially becoming a front for dispute and pressure. 
contacts in the government, i.e., the Minister of Agriculture, to convince the president about the importance of keeping the partnership alive (WIZIACK, 2020).

This episode shows the tension inside the Brazilian government concerning the handling of the relationship with China but also how domestic political alliances can shift in response to the transformations of the global sphere. In a very similar fashion than traditional conditionality in the 1980s, national governments are constrained to behave in a certain way so as to accommodate the interests of their creditors. While cross-conditionality does not lead to politically costly institutional reforms, its presence does affect governments' coalition-building efforts because it has the potential to set apart domestic political partnerships. Current circumstances might make Brazilian agribusiness less vulnerable to Chinese retaliation via cross-conditionality, however, their intense mobilization indicates that the risk is more than latent when infrastructure projects, and investment more broadly, are considered. This would not only represent a risk for the Brazilian government in the international arena but, perhaps more importantly, in its efforts to gather a governing coalition at home.

\section{Conclusions}

The goal of this contribution was to analyze the political consequences in Brazilian domestic politics associated with the strategy of cross-conditionality that Chinese authorities have implemented in the past. Considering this is important given the changes that the turn to the Right have brought to the conduction of Latin America's relationship with China. We analyzed the Brazilian case after the election of Jair Bolsonaro through an asymmetric comparison. The support that the Agribusiness Parliamentary Group (Bancada ruralista) gives to Bolsonaro's government offers an ideal setting to study this issue. Agricultural commodities constitute an important part of the commercial relation between Brazil and China. We conclude that cross-conditionality represents a considerable risk, although not immediate, to coalitionbuilding efforts of governments that rely on agribusiness given the importance of commodity trade between China and Brazil. This outcome is in line with what the literature on the Second Image Reversed suggested about the empowerment of social groups that participated heavily in international trade.

Other sectors, such as infrastructure, can also be the targets of cross-conditionality given the hefty investments that China, whether through state-owned companies or state-backed ones, have done or plan to do in that realm (VILANOVA, 2019). However, we consider that this sector in Brazil is less vulnerable to a retaliatory action in the lines of cross conditionality. The reason for this difference is the presence of the BNDES and the possibilities it offers as a substitute for Chinese financial resources. Thus, this reproduces the patterns observed in the 1980 s when the financial means of a state made it more or less vulnerable to conditionality clauses attached to structural adjustment loans. However, hostilities towards Chinese participation in infrastructure projects, might translate into retaliation - in the same way that crossconditionality would work - in the realm of international trade where commodities dominate.

In consequence, cross-conditionality more broadly represents only a moderate risk to the coalition-building efforts of the current Brazilian government. However, those risks can easily escalate if the Brazilian government continues to nurture the animosity against China that was evident before it took office. The Chinese government might weight its options differently if the global landscape changes towards a less confrontational scenario, which includes a friendly government in Argentina. This risk is substantial given the strong negative correlation between Argentinean and Brazilian exports, which potentially indicate that Latin American soybean exports are a zero-sum game. Those risks are well understood by the Brazilian Agribusiness Parliamentary Groups which has repeatedly voiced its uneasiness with ideological statements blatantly hostile to China made by members of the Brazilian government. Whether those manifestations are sign of the strength or weakness of their position within the government is an empirical matter. They highlight however the impact of cross-conditionality in the coalition building efforts of a rather fragile government. 


\section{References}

ABDENUR, Adriana. E.; FOLLY, Maiara. The New Development Bank and the Institutionalization of the BRICS. In: FUNAG, Fundação Alexandre de Gusmão. (Ed.). BRICS. Studies and Documents. Chapter 3, p.77-111. Brasília, DF: Fundação Alexandre de Gusmão - FUNAG, 2017.

ALT, James E. et al. The Political Economy of International Trade. Comparative Political Studies, [s. 1.], v. 29, n. 6, p. 689-717, 1996.

AVENDANO, Rolando.; MELGUIZO, Angel.; MINER, Sean. Chinese FDI in Latin America: New Trends with Global Implications. Washington, DC/Paris: Atlantic Council/OECD Development Centre, 2017.

BADIN, Cláudio. Inovação na Gestão ao Mercado Externo. RAE eletrônica, 2, n.1, 2003. Available at:

http://www.scielo.br/scielo.php?script=sci_arttext\&pid=S1676-56482003000100005\&nrm=iso. Access in: August 12, 2020

BAUMANN, Renato.; RIVERO, Josefina.; ZAVATTIERO, Yohana. As Tarifas de Importação no Plano Real. Pesquisa e Planejamento Econômico, v.27, n.3, p.541-586, 1997.

BNDES. Banco Nacional de Desenvolvimento Econômico e Social. BNDES aprova R\$ 5,2 bilhões para linha de transmissão de UHE Belo Monte (PA) ao RJ. Rio de Janeiro, RJ, p.Press release, November 19, 2018. Available at:

https://www.bndes.gov.br/wps/portal/site/home/imprensa/noticias/conteudo/bndes-aprova-r-5-2-bilhoes-para-linha-de-transmissao-de-uhe-belomonte-pa-ao-rj. Access in: April 23, 2019.

BONELLI, Regis.; PINHEIRO, Armando. C. Abertura e Crescimento Econômico no Brasil. In: BARROS, Octavio. de GIAMBIAGI, Fabio. (Ed.). Brasil Globalizado. O Brasil em um Mundo Surpreendente. Chapter 3, p.89-124. Rio de Janeiro: Elsevier, 2008.

BRASIL, Ministério de Economia.-República Federativa do. Blocos e Países. Séries Históricas. Estatísticas de Comércio Exterior, Ministério de Economia. Brasília, DF 2020.

BRUNO, Regina. Bancada Ruralista, Conservadorismo e Representação de Interesses no Brasil Contemporâneo. In: MALUF, Renato. S. e FLEXOR, Georges. (Ed.). Questões Agrárias, Agrícolas e Rurais. Conjunturas e Políticas Públicas. Chapter 13, p.155-168. Rio de Janeiro: E-papers/CPDAUFRRJ, 2017.

CAMERON, Maxwell. A.; HERSHBERG, Eric. (ed.). Latin America's Left Turns: Politics, Policies, and Trajectories of Change. Boulder, CO: Lynne Rienner Publishers, 2010.

CHANTAL, Roromme. L'émergence des grandes puissances: pouvoir symbolique et nouveau rôle de la Chine dans le monde après la Guerre froide. Doctoral Thesis in (Political Science), Université de Montréal, 2015.

CHATIN, Mathilde. Brésil: la politique étrangère de Jair Bolsonaro. Politique étrangère, n.2, p.115-127, 2019.

COHEN, Benjamin. J. International Political Economy. An Intellectual History. Princeton, NJ: Princeton University Press, 2008.

CRIVELLI, Eduardo.; LO-BRUTTO, Giusseppe. La cooperación de China en América Latina: ¿hacia una Nueva Economía Estructural? Carta Internacional, v.13, n.2, p.123-146, 2018

DAIA FIRMIANO, Frederico. "Quem lamenta os estragos - se os frutos são prazeres?" O bloco de poder agro do governo Bolsonaro. Estudos Sociedade e Agricultura, v.28, n.2, p.364-387, 2020.

DAUVERGNE, Peter.; FARIAS, Déborah. BL. The Rise of Brazil as a Global Development Power. Third World Quarterly, v.33, n.5, p.903-917, 2012.

DAVIS, Donald. R.; MISHRA, Prachi. Stolper-Samuelson Is Dead: And Other Crimes of Both Theory and Data. In: HARRISON, Ann.(Ed.). Globalization and Poverty. Chapter 2, p.87-107. Chicago, IL: University of Chicago Press, 2007.

DUARTE, Paulo. Soft China: O Caráter Evolutivo da Estratégia de Charme Chinesa. Contexto Internacional, v.34, n.2, p.501-529, 2012.

DUARTE, Rafael.; VIANA, Manuela Trindade. Política Exterior Brasileña: Nuevos y Viejos Caminos en los Aspectos Institucionales, en la Práctica del Multilateralismo y en la Política para el Sur Revista de Ciencia Política, v.28, n.2, p.77-106, 2008.

ECONOMIST. Why you should never start a trade war with an autocracy. p.Webpage, April 27, 2019. Available at: https://www.economist.com/graphic-detail/2019/04/27/why-you-should-never-start-a-trade-war-with-an-autocracy. Access in: August 6, 2020.

ELLIS, R. Evan. China on the Ground in Latin America. New York, NY: Palgrave Macmillan, 2014.

FARIA, Carlos Alberto Pimenta de. O Itamaraty e a Política Externa Brasileira: Do Insulamento à Busca de Coordenação dos Atores Governamentais e de Cooperação com os Agentes Societários. Contexto Internacional, v.34, n.1, p.311-355, Janeiro-Junho 2012.

FLORES, Fidel. P.; JATOBÁ, Daniel. Domestic Reactions to China's Presence in Three Latin American Countries: Brazil, Nicaragua and Venezuela. Journal of China and International Relations, v.4, n.Special Issue, p.128-150, 2016.

FRIEDEN, Jeffry. A; LAKE, David. A.; BROZ, J. Lawrence. (ed.). International Political Economy. Perspectives on Global Power and Wealth. 6 ed. New York, NY/London: W. W. Norton \& Company, 2017.

FRIEDEN, Jeffry. A; MARTIN, Lisa. L. International Political Economy: Global and Domestic Interactions. In: KATZNELSON, Ira. e MILNER, Helen. V. (Ed.). Political Science: The State of the Discipline. Chapter 4, p.118-146. New York: W. W. Norton \& Company, 2002.

FRIEDEN, Jeffry. A. Debt, Development, and Democracy: Modern Political Economy and Latin America, 1965-1985. Princeton: Princeton University Press, 1991. 
GALLAGHER, Kevin. P. The China Triangle. Latin America's China Boom and the Fate of the Washington Consensus. New York, NY: Oxford University Press, 2016.

GAZIBO, Mamoudou. La démarche comparative binaire : éléments méthodologiques a partir d'une analyse de trajectoires contrastées de démocratisation. Revue internationale de politique comparée, v.9, n.3, p.427-449, 2002.

GOUREVITCH, Peter. The Second Image Reversed: The International Sources of Domestic Politics. International Organizations, v.32, n.4, p.881-912, 1978.

HAGGARD, Stephen.; MAXFIELD, Sylvia. The Political Economy of Financial Internationalization in the Developing World. International Organizations, v.50, n.1, p.35-68, 1996.

HASSENTEUFEL, Patrick. Deux ou trois choses que je sais d'elle. Remarques à propos d'expériences de comparaisons européennes. In: BACHIR, Myriam.; DUCHESNE, Sophie., et al (Ed.). Les méthodes au concret. Démarches, formes de l'expérience et terrains d'investigation en science politique. Chapter 6. p.105-124. Paris: PUF, 2000.

IGLÉCIAS, Wagner. O Empresariado do Agronegócio no Brasil: Ação Coletiva e Formas de Atuação Política - As Batalhas do Açúcar e do Algodão na OMC. Revista de Sociologia e Política, v.28, p.75-97, 2007.

JOHNSON, Juliet et al. The future of international political economy: Introduction to the 20th anniversary issue of RIPE. Review of International Political Economy, v.20, n.5, p.1009-1023, 2013

KATZENSTEIN, Peter. J. (ed.). Between Power and Plenty: Foreign Economic Policies of Advanced Industrial States. Madison, WI: University of Wisconsin Press, 1978.

KATZENSTEIN, Peter. J. Small States in World Markets: Industrial Policy in Europe. Ithaca, NY: Cornell University Press, 1985

KENT, Ann. China's Participation in International Organisations. In: ZHANG, Y. e AUSTIN, G. (Ed.). Power and Responsibility in Chinese Foreign Policy. Canberra: Australian National University E Press, 2013. Chapter 6, p.132-166

KEOHANE, Robert. O.; MILNER, Helen. V. (ed.). Internationalization and Domestic Politics. Cambridge: Cambridge University Press, 1996.

KOCKA, Jürgen. Asymmetrical Historical Comparison: The Case of the German Sonderweg. History and Theory, v.38, n.1, p.40-50, 1999.

KUME, Honorio.; PIANI, Guida.; SOUZA, Carlos Frederico Braz de. A Política Brasileira de Importação no Período 1987-1998: Descrição e Avaliação. In: CORSEUIL, Carlos Henrique. and KUME, Honorio. (Ed.). A Abertura Comercial Brasileira nos Anos 1990. Impactos sobre Emprego e Salário. Chapter 1, p.9-37. Rio de Janeiro: Ministério do Trabalho e do Emprego/IPEA, 2003.

LAKE, David. A. International Political Economy. A Maturing Discipline. In: WITTMAN, Donald. A. and WEINGAST, Barry. R. (Ed.). The Oxford Handbook of Political Economy. Chapter 42, p.757-777. Oxford: Oxford University Press, 2006.

LANTEIGNE, Marc. Chinese Foreign Policy. An Introduction. 4 ed. Abingdon: Routledge, 2020.

LEVITSKY, Steven.; ROBERTS, Kenneth. M. (ed.). The Resurgence of the Latin American Left. Baltimore: Johns Hopkins University Press, 2011.

LIBÂNIO, Gilberto. Mr. Bolsonaro e os Chineses: uma sugestão de interpretação. Brazilian Keynesian Review, v.4, n.2, p.300-312, 2018.

MALACALZA, Bernabé. La Política de la Cooperación Sur-Sur. China, India y Brasil en América Latina y el Caribe. Colombia Internacional, n.98, p.67$103,2019$.

MALINIAK, Daniel.; TIERNEY, Michael. J. The American school of IPE. Review of International Political Economy, v.16, n.1, p.6-33, 2009.

MATTLIN, Mikael.; NOJONEN, Matti. Conditionality and Path Dependence in Chinese Lending. Journal of Contemporary China, v.24, n.94, p.701-720, 2015.

MAXFIELD, Sylvia. Gatekeepers of Growth. The International Political Economy of Central Banking in Developing Countires. Princeton: Princeton University Press, 1997.

O'DONNELL, Guillermo. A. On the State, Democratization and Some Conceptual Problems: A Latin American View with Glances at Some Postcommunist Countries. World Development, v.21, n.8, p.1355-1369, 1993

OURIQUES, Helton. R.; ARIENTI, Patrícia. F. F. O Retorno de uma Ilusão: As Relações Econômicas entre Brasil e China (2000-2015). In: MARIANO, Karina. L. P.; MENEZES, Roberto. G., et al (Ed.). Mundo em Transição. Novos Vértices de Poder, Instituições e Cooperação. Chapter 14, p.341-363. Dourados, MS: Editora UFGD, 2017.

OVIEDO, Eduardo. D. Argentina y China: causas de la disputa en torno al aceite de soja. Estudios de Asia y África, v47, n.2, p.337-376, 2012.

PATEY, Luke. China Made Mauricio Macri a Deal He Couldn't Refuse. Foreign Policy. Online Article, January 24, 2017. Available at: https://foreignpolicy.com/2017/01/24/china-made-mauricio-macri-a-deal-he-couldnt-refuse/. Access in: April $22,2019$.

PECEQUILLO, Cristina. Sonerau. A Política Externa do Brasil no Século XXI: Os Eixos Combinados de Cooperação Horizontal e Vertical. Revista Brasileira de Política Internacional, v.51, n.2, p.136-153, Julio-Diciembre 2008.

PEET, Richard. Unholy Trinity. The IMF, World Bank and WTO. 2nd ed. London/New York, NY: Zed Books, 2009.

PINHO, Carlos Eduardo Santos. Cooperación Sur-Sur para el Desarrollo: las Relaciones Brasil-África en la promoción de las Políticas Públicas (20032012). América Latina Hoy, v.63, p.91-112, 2013. 
PITTAS, Tiago Mocellin.; DRI, Clarissa Franzoi. O Diálogo entre Saúde e Política Externa na Cooperação Brasileira em Bancos de Leite Humano. Ciência \& Saúde Coletiva, 22, n.7, p.2277-2286, 2017.

RAGIN, Charles.; ZARET, David. Theory and Method in Comparative Research: Two Strategies. Social Forces, v.61, n.3, p.731-754, 1983.

RIBEIRO, Jackson.; MARINGONI, Gilberto. O Banco e o Arranjo de Reserva dos BRICS em Perspectiva. Brazilian Journal of International Relations, v.8, n.2, p.406-426, 2019.

RIBEIRO, Renata. A.; MILANI, Carlos. R. S. L'élection de Bolsonaro, la politique étrangère brésilienne en 2019 et l'avenir de la coopération Sud-Sud. IdeAs, n.13, 2019. DOI: 10.4000/ideas.5578. Available at: http://journals.openedition.org/ideas/5578. Access in: August 5, 2020.

RITTNER, Daniel.; KRÜGER, Ana.; ARAÚJO, Carla. Retórica anti-China trava uso de fundo bilionário no Brasil. Valor Econômico, Rio de Janeiro, RJ, p.A6, March 7, 2019. Brasil, p.A1. Available at: https://valor.globo.com/brasil/noticia/2019/03/07/retorica-anti-china-trava-uso-de-fundo-bilionariono-brasil.ghtml. Access in: August 12, 2020

ROCHA, Felipe. F. d.; BIELSCHOWSKY, Ricardo. La Búsqueda de China de Recursos Naturales en América Latina. Revista CEPAL, n.126, p.9-29, 2018.

ROGOWSKI, Ronald. Commerce and Coalitions. How Trade Affects Domestic Political Alignments. Princeton, NJ: Princeton University Press, 1989.

ROHLFING, Ingo. Case Studies and Causal Inference: An Integrative Framework. Basingstoke: Palgrave Macmillan, 2012.

ROLDÁN, Adriana et al. La presencia China en América Latina, comercio inversión y cooperación económica, Medellín, Fundación Konrad Adenauer/Universidad EAFIT, 2016.

SAMORA, Roberto. Comunicação do governo Bolsonaro sobre agronegócio mais atrapalha que ajuda, diz OCB. Brasil247, August 3, 2020. Available at: https://www.brasil247.com/economia/comunicacao-do-governo-bolsonaro-sobre-agronegocio-mais-atrapalha-que-ajuda-diz-ocb. Access in August $6,2020$.

SHAPIRO, Ian. Problems, Methods, and Theories in the Study of Politics, or What's Wrong with Political Science and What to Do About it. Political Theory, v.30, n.4, p.596-619, 2002.

SILVA, Fabiana. K.; MENDONÇA, Talles. G. Evolução do comércio bilateral entre Brasil e China: análise das relações comerciais. Economia e Desenvolvimento, v.29, n.2, p.73-90, 2017.

SINGH, Shivani. China's soybean imports from Brazil rise to record in June. Reuters, Beijing, July 26, 2020. Available at: https://www.reuters.com/article/us-china-economy-trade-soybeans/chinas-soybean-imports-from-brazil-rise-to-record-in-june-idUSKCN24R07Q. Access in: August 6, 2020

STOLPER, Wolfgang. F.; SAMUELSON, Paul. A. Protection and Real Wages. The Review of Economic Studies, v.9, n.1, p.58-73, 1941.

UN COMTRADE. Soybeans exports: United Nations Comtrade Database. Commodity Code 1201 - Soybeans, whether or not broken. 2020. Available at: http://comtrade.un.org/data. Access in: September 27, 2020.

VADELL, Javier. A. El Foro China-CELAC y el Nuevo Regionalismo para un Mundo Multipolar: Desafíos para la Cooperación 'Sur-Sur'. Carta Internacional, v.13, n.1, p.6-37, 2018.

VILA-NOVA, C. China mira América Latina em seu maior projeto de influência exterior. Folha de S.Paulo, São Paulo, March 24, 2019. Available at: https://www1.folha.uol.com.br/mundo/2019/03/china-mira-america-latina-em-seu-maior-projeto-de-influencia-exterior.shtml. Access in: August 13, 2020.

WALTZ, Kenneth. N. Theory of International Politics. Reading, MA: Addison-Wesley Publishing, 1979.

WALTZ, Kenneth. N. Man, the State, and War: A Theoretical Analysis. 2nd ed. New York, NY: Columbia University Press, 2001.

WIZIACK, Julio. Brasil cria travas que dificultam investimentos chinês no país. Folha de S.Paulo, São Paulo, August 8, 2020. Available at: https:/www1.folha.uol.com.br/mercado/2020/08/brasil-cria-travas-que-dificultam-investimentos-chines-no-pais.shtml. Access in: August 9, 2020.

WOODS, Ngaire. The Globalizers. The IMF, the World Bank and Their Borrowers. Ithaca, NY: Cornell University Press, 2006.

Authors' Contributor Roles 